\title{
Preparation and comparison of cytotoxic complexes formed between oleic acid and either bovine or human $\alpha$-lactalbumin
}

\author{
C. R. Brinkmann, ${ }^{\star} \dagger$ S. Thiel, $\nmid$ M. K. Larsen, $\neq$ T. E. Petersen, ${ }^{\star 1}$ J. C. Jensenius, $†$ and C. W. Heegaard ${ }^{\star}$ \\ ${ }^{*}$ The Protein Chemistry Laboratory, Department of Molecular Biology, Aarhus University, Science Park, Gustav Wieds Vej 10, \\ DK-8000 Aarhus C, Denmark \\ †Department of Medical Microbiology and Immunology, Faculty of Health Sciences, Aarhus University, Wilhelm Meyers Allé 4, \\ DK-8000 Aarhus C, Denmark \\ ‡Department of Food Science, Faculty of Agricultural Sciences, Aarhus University, Blichers Allé, PO Box 50, DK-8830 Tjele, Denmark
}

\begin{abstract}
$\alpha$-Lactalbumin is a ubiquitous calcium-binding milk protein with a well-characterized function in regulating the synthesis of lactose. An entirely different activity has been shown to occur when a complex is formed between calcium-free $\alpha$-lactalbumin and oleic acid. This complex shows strong cytotoxic action against several cancer cells, and several mechanisms have been suggested to account for this cell-killing activity. Most studies have been performed using the human protein, but bovine $\alpha$-lactalbumin shows similar activity. A new and simple 2-step method for purification of calciumfree $\alpha$-lactalbumin has been developed, and the resulting highly purified preparation was used to generate a complex with oleic acid. Using 3 different cell lines and 2 types of cell viability assays, the bovine and human $\alpha$-lactalbumin showed comparable cytotoxic activity. The effect was apparent after 15 min of incubation and was inhibited by the presence of fetal bovine serum or bovine serum albumin. The bovine protein might be a useful alternative to the human protein, but also raises the question whether cytotoxic activity could be generated in different kinds of food containing $\alpha$-lactalbumin.
\end{abstract}

Key words: alpha-lactalbumin, BAMLET, cytotoxicity, oleic acid

\section{INTRODUCTION}

The milk protein $\alpha$-LA is essentially unique for all mammals and has a well-described function in the synthesis of lactose in the mammary gland (Fox, 1998). By forming a complex with $\beta$-1,4-galactosyltransferase, the specificity of the enzyme is changed so it catalyzes the formation of lactose by transferring galactose to glucose instead of $N$-acetylglycosamine. Bovine $\alpha$-LA

Received July 14, 2010.

Accepted January 24, 2011.

${ }^{1}$ Corresponding author: tep@mb.au.dk consists of 123 AA with 4 disulfide bonds, and although it contains 2 potential sites for N-glycosylation (AsnXxx-Ser), most of the protein is free of carbohydrate. The protein has a strong calcium-binding site, which accelerates the folding process, whereas in the absence of calcium, $\alpha$-LA adopts a more loose structure described as a molten globule state (Kronman et al., 1981).

In the last few years, a remarkable apoptotic-like activity toward cultured cancer cells of a complex between the calcium-free form of human $\alpha-\mathrm{LA}$ and oleic acid (OA) has been described (Mok et al., 2007). The complex could either be isolated from human milk (Håkansson et al., 1995) or formed on a diethylaminoethyl (DEAE) trisacryl column equilibrated with OA (Svensson et al., 2000). The complex was named HAMLET (human alpha-lactalbumin made lethal to tumor cells). When tested against several different cell types, HAMLET was reported by Svanborg et al. (2003) to show strongest activity against tumor cells, whereas mature differentiated cells were not affected.

In contrast to human milk, no similar naturally occurring activity was found in bovine milk (Pettersson et al., 2006). However, it has been possible to make a complex between bovine $\alpha$-LA and OA called BAMLET (bovine alpha-lactalbumin made lethal to tumor cells), capable of inducing cell death in transformed cells in vitro (Pettersson et al., 2006). In bovine milk, $\alpha-\mathrm{LA}$ is present at a concentration of $1.2 \mathrm{~g} / \mathrm{kg}$, corresponding to $3.7 \%$ of the total protein content. In the production of cheese, most of the $\alpha$-LA is left in the whey fraction, which is often added to different food types as a stabilizing ingredient. Accordingly, $\alpha-\mathrm{LA}$ is present not only in dairy products, but also in many other food categories. In human milk, $\alpha$-LA is a major protein, corresponding to about $15 \%$ of total protein. As a consequence, bovine $\alpha-\mathrm{LA}$ is regularly included in instant formulas. It is, therefore, of interest to investigate conditions for generating BAMLET-like activity that could potentially modulate the growth of cells (e.g., in the intestine). 
The complex HAMLET, prepared from $\alpha$-LA purified from human breast milk and OA, as described by Svensson et al. 2000, has shown promising clinical trials on treatment of skin papillomas (Gustafsson et al., 2004) and bladder cancer (Mossberg et al., 2007). If HAMLET is shown to be efficacious in further clinical trials, large-scale production of HAMLET will be required for the treatment of cancer patients, and this may be hampered by the limited quantities of human breast milk available.

The present report examines whether differences in preparation procedures and starting material (human or bovine milk) affects the cytotoxicity of the final product. We present a new alternative procedure for the preparation of HAMLET and the bovine equivalent, BAMLET, and investigate the cytotoxicity of the resulting products in the 2 human leukemic cell lines, HL-60 (promyelocytic) and U937 (monocytic) and the solid ovarian carcinoma cell line, Skov-3.

\section{MATERIALS AND METHODS}

All buffers were prepared from analytical grade chemicals purchased from Sigma-Aldrich (Brøndby, Denmark) or Merck (Hellerup, Denmark). The following cell lines were used: HL-60 (human promyelocytic leukemia-derived cell line from Deutsche Sammlung von Mikroorganismen und Zellkulturen, code ACC3), U-937 [human monocytic cell line derived from a histiocytic lymphoma from the American Type Culture Collection (ATCC), code CRL1593.2] and SKOV-3 (human ovarian adenocarcinomaderived cell line from ATCC, code HTB-77).

\section{Purification of $\alpha-L A$}

$\alpha$-Lactalbumin was purified from fresh bovine milk or from frozen human breast milk. For purification of bovine $\alpha$-LA, $1 \mathrm{~L}$ of milk, freshly collected from a local farm, was centrifuged at $4,600 \times g$ for $25 \mathrm{~min}$ and the fat was removed. The skim milk was adjusted to $\mathrm{pH} 4.3$ by the addition of $2 \mathrm{M} \mathrm{HCl}$, and the whey was separated from the precipitated casein by centrifugation at $4,600 \times g$ for $30 \mathrm{~min}$. The whey was filtered through glass wool to remove residual fat. Calcium chloride was added to the whey to reach a final concentration of 1 $\mathrm{m} M$ and the $\mathrm{pH}$ adjusted to 7.4 with $2 \mathrm{M} \mathrm{NaOH}$. The whey was dialyzed overnight at $4^{\circ} \mathrm{C}$ against $10 \mathrm{~L}$ of 10 $\mathrm{m} M$ Tris, $1 \mathrm{mM} \mathrm{CaCl} 2$, $\mathrm{pH} 7.4$, and centrifuged for 30 $\min$ at $15,200 \times \mathrm{g}$. The conductivity of the dialyzed supernatant was below $2.0 \mathrm{mS}$. Five hundred milliliters of whey was loaded onto a DEAE Sepharose Fast Flow column $(2.5 \mathrm{~cm} \times 40 \mathrm{~cm}$, GE Healthcare, Brøndby, Denmark) at a flow rate of $100 \mathrm{~mL} / \mathrm{h}$. The column was developed with a linear gradient of 0 to $0.3 \mathrm{M} \mathrm{NaCl}$ in the same buffer and flow rate, and 10-mL fractions were collected. The $\alpha$-LA-containing fractions were identified by SDS-PAGE, followed by Western blotting using affinity purified anti- $\alpha$-LA antibody (A10-128P, Bethyl Laboratories, Montgomery, TX) and N-terminal AA sequencing carried out by automated Edman degradation (Procise Protein Sequencing System Model 491, Applied Biosystems by Life Technologies, Carlsbad, CA). The fractions containing the protein of interest were pooled, EDTA was added to a final concentration of $5 \mathrm{mM}$, and the mixture stirred for $1 \mathrm{~h}$ at room temperature. The calcium-depleted $\alpha$-LA-enriched pool was then dialyzed for $5 \mathrm{~h}$ at $4^{\circ} \mathrm{C}$ against $10 \mathrm{mM} \mathrm{NH} \mathrm{NCO}_{3}$, $\mathrm{pH}$ 7.9. The dialysate was loaded onto a second DEAE Sepharose Fast Flow column $(2.5 \mathrm{~cm} \times 40 \mathrm{~cm})$ at a flow rate of $54 \mathrm{~mL} / \mathrm{h}$ and eluted with a $3-\mathrm{L} \mathrm{NH}_{4} \mathrm{HCO}_{3}$ gradient (50 to $300 \mathrm{mM}$ ). The fractions containing pure $\alpha$-LA were identified as above, pooled, lyophilized and stored at $-20^{\circ} \mathrm{C}$ until use. Human $\alpha$-LA was purified as described above, with the exceptions that the initial volume of whey was $300 \mathrm{~mL}$ (1 donor) and that the size of the DEAE Sepharose columns used was decreased to $2.5 \mathrm{~cm} \times 30 \mathrm{~cm}$ and $2.5 \mathrm{~cm} \times 25 \mathrm{~cm}$, respectively.

For qualitative and quantitative comparison of the cytotoxic potential, human and bovine $\alpha$-LA was also purified as described previously by Svanborg and colleagues (Lindahl and Vogel, 1984; Svensson et al., 2000). In brief, frozen bovine or human milk from multiple donors was thawed and centrifuged, and the milk fat was removed. Whey was prepared by adding $264 \mathrm{~g}$ of ammonium sulfate per liter of milk, followed by incubation overnight at $4^{\circ} \mathrm{C}$. The precipitated proteins were removed by centrifugation for $20 \mathrm{~min}$ at $40,000 \times g$, and $\alpha$-LA was purified from the whey by hydrophobic interaction chromatography. A chromatography column was prepared with $300 \mathrm{~mL}$ of Phenyl Sepharose 6 Fast Flow (GE Healthcare) in a XK50 column (GE Healthcare). Ethylenediaminotetraacetate and Tris were added to the whey to obtain $48 \mathrm{~m} M$ EDTA and $50 \mathrm{~m} M$ Tris, and the $\mathrm{pH}$ was adjusted to 7.5. The whey was loaded onto the column, followed by washing with $1 \mathrm{~m} M$ EDTA, 50 $\mathrm{m} M$ Tris, $\mathrm{pH} 7.5$, and $\alpha-\mathrm{LA}$ was eluted with a low ionic strength $\mathrm{Ca}^{2+}$-containing buffer $\left(1 \mathrm{mM} \mathrm{CaCl}_{2}, 50 \mathrm{mM}\right.$ Tris, $\mathrm{pH}$ 7.5). The loading of whey, followed by elution of $\alpha$-LA was repeated 3 times on the same column, and the eluted $\alpha$-LA-containing fractions were pooled and either dialyzed against water and lyophilized, or used immediately for conversion to bovine or human $\alpha$-LA:OA complexes.

\section{Preparation of $\alpha-L A: O l e i c$ Acid Complexes}

Seventy milligrams of purified bovine or human $\alpha$-LA was dissolved in $30 \mathrm{~mL}$ of EDTA-containing buffer (10 
$\mathrm{m} M$ Tris, $0.08 \mathrm{~m} M$ EDTA, $\mathrm{pH}$ 8.5) with stirring at room temperature. Thirty microliters of OA (SigmaAldrich), was dissolved in $400 \mu \mathrm{L}$ of $96 \%$ ethanol with mixing for 3 min. Eighty-four grams of DEAE Sepharose Fast Flow was dispersed in $25 \mathrm{~mL}$ of $10 \mathrm{~m} M$ Tris, $\mathrm{pH} 8.5$, and the OA:ethanol mix was added dropwise, followed by $3 \times 5$ min of sonication (ultrasonic cleaner, Model 200, Branson Ultrasonic Corporation, Danbury, $\mathrm{CT})$. A $2.5 \mathrm{~cm} \times 20 \mathrm{~cm}$ column was prepared from the OA-conditioned DEAE Sepharose. To remove unbound $\mathrm{OA}$, the column was washed with $100 \mathrm{~mL}$ of $1 \mathrm{M} \mathrm{NaCl}$, $10 \mathrm{~m} M$ Tris, $\mathrm{pH}$ 8.5, followed by equilibration with 10 $\mathrm{m} M$ Tris, $\mathrm{pH}$ 8.5. The $\alpha-\mathrm{LA}$ in the EDTA-containing buffer was loaded onto the column (flow rate $40 \mathrm{~mL} / \mathrm{h}$ ). Unbound $\alpha$-LA was removed by washing with $0.2 \mathrm{M}$ $\mathrm{NaCl}, 10 \mathrm{~m} M$ Tris, $\mathrm{pH} 8.5$, and the $\alpha$-LA:OA complex was eluted using $1 \mathrm{M} \mathrm{NaCl}, 10 \mathrm{~m} M$ Tris, $\mathrm{pH}$ 8.5. The eluate was dialyzed against $10 \mathrm{~L}$ of PBS $(138 \mathrm{mM}$ $\mathrm{NaCl}, 2.7 \mathrm{~m} M \mathrm{KCl}, 8 \mathrm{~m} M \mathrm{Na}_{2} \mathrm{HPO}_{4}, 1.5 \mathrm{~m} M \mathrm{KH}_{2} \mathrm{PO}_{4}$, $\mathrm{pH}$ 7.4) and concentrated to approximately $2 \mathrm{mg} / \mathrm{mL}$ using an Amicon stirred cell with an Ultracell Amicon Ultrafiltration Disc membrane (molecular weight cut-off $=10,000$ Da; Millipore, Copenhagen, Denmark). The samples were frozen and kept at $-20^{\circ} \mathrm{C}$ until use. In the subsequent sections, the products obtained by this method are referred to as BAMLET and HAMLET.

The conventional cytotoxic $\alpha$-LA:OA complex was prepared from human or bovine $\alpha$-LA, as previously described by Svensson et al. (2000). Briefly, $40 \mu \mathrm{L}$ of OA was dissolved in $500 \mu \mathrm{L}$ of $99 \%$ ethanol and mixed with $20 \mathrm{~mL}$ of buffer $(10 \mathrm{~m} M$ Tris, $0.1 \mathrm{M} \mathrm{NaCl}, \mathrm{pH}$ 8.5). The resulting mixture was loaded onto $100 \mathrm{~mL}$ of DEAE Trisacryl M (BioSepra, Pall Corp., SaintGermain-en-Laye, France), packed in a XK50 column (GE Healthcare). Excess OA was removed by washing with $10 \mathrm{~m} M$ Tris, $\mathrm{pH}$ 8.5, containing first $100 \mathrm{mM}$ $\mathrm{NaCl}$, followed by a gradient of $\mathrm{NaCl}$ up to $235 \mathrm{mM}$, then washing sequentially with $10 \mathrm{~m} M$ Tris, $\mathrm{pH} 8.5$, containing $730 \mathrm{~m} M \mathrm{NaCl}, 100 \mathrm{~m} M \mathrm{NaCl}, 1 M \mathrm{NaCl}$, and $100 \mathrm{~m} M \mathrm{NaCl}$. This scheme was repeated in the following wash sequence and elution of bovine and human $\alpha$-LA:OA complexes.

Before loading onto the OA-conditioned column, EDTA was added to the $\alpha$-LA eluted from the Phenyl Sepharose column to achieve a final concentration of $36 \mathrm{~m} M$ EDTA. The $\mathrm{NaCl}$ gradient scheme given above was repeated; first to remove excess $\alpha$-LA (eluting in the salt gradient from $100 \mathrm{~m} M$ to $235 \mathrm{mM} \mathrm{NaCl}$ ) and then to elute bovine and human $\alpha$-LA:OA complexes (both eluting at $730 \mathrm{mM} \mathrm{NaCl}$ in the elution scheme). To achieve a larger amount of material, loading of $\alpha-\mathrm{LA}$ and the $\mathrm{NaCl}$ gradient program was repeated 4 times on the same column without further conditioning with OA between runs. Fractions eluted with $730 \mathrm{mM} \mathrm{NaCl}$ were collected and pooled before dialysis $(6$ times against $5 \mathrm{~L}$ of water) and lyophilization. In the following sections, the products obtained by this conventional method are referred to as BAMLET-conventional and HAMLETconventional. The protein content of all samples was determined by acid hydrolysis followed by quantitative AA analysis. Thus, unless otherwise indicated, all concentrations of BAMLET and HAMLET refer to the amount of $\alpha$-LA in the complex.

\section{Determination of the Oleic Acid Content of BAMLET and HAMLET}

The OA content of all of the complexes studied was determined essentially as described by Palmquist and Jenkins (2003). An OA standard curve was prepared by adding $0,10,25$, and $50 \mu \mathrm{L}$ of an $\mathrm{OA} /$ dichloromethane solution (1 $\mathrm{mg}$ of $\mathrm{OA} / \mathrm{mL}$ of dichloromethane) to separate tubes (in duplicate). As an internal standard, 50 $\mu \mathrm{L}$ of palmitic acid dissolved in dichloromethane $(2 \mathrm{mg}$ of palmitic acid $/ \mathrm{mL}$ of dichloromethane) was added to each tube used for the standard curve as well as to the tubes used for the test samples. After evaporation of dichloromethane in a fume cupboard for $30 \mathrm{~min}, 100$ $\mu \mathrm{L}$ of PBS was added to the OA tubes and $100 \mu \mathrm{L}$ of the HAMLET or BAMLET samples was added to the sample tubes (in duplicate). To prepare derivatives of $\mathrm{OA}$ and palmitic acid for GC, methyl esters were formed by the addition of $1.5 \mathrm{~mL}$ of $10 \%$ methanolic $\mathrm{HCl}$ (prepared by slowly adding $20 \mathrm{~mL}$ of acetyl chloride to $100 \mathrm{~mL}$ of dry methanol while stirring) and 1 $\mathrm{mL}$ of heptane to each tube, followed by heating to $90^{\circ} \mathrm{C}$ for $2 \mathrm{~h}$. After cooling on ice, $1 \mathrm{~mL}$ of heptane and $3 \mathrm{~mL}$ of $10 \% \mathrm{~K}_{2} \mathrm{CO}_{3}$ were added to each tube, followed by vortexing and centrifugation $(500 \times g, 5$ min). The heptane phase (the upper phase) containing the fatty acid methyl esters was transferred to GC vials. Samples were analyzed on a HP6890 GC system (Hewlett Packard Co., Palo Alto, CA) with a flameionization detector and a Restek Rt 2560 column (100 $\mathrm{m} \times 0.25 \mathrm{~mm} \times 0.20 \mu \mathrm{m}$; Restek US, Bellefonte, PA) . The inlet temperature was $275^{\circ} \mathrm{C}$ with a split ratio of $40: 1$, and the carrier gas was helium with a constant flow of $1.5 \mathrm{~mL} / \mathrm{min}$. The starting temperature of $140^{\circ} \mathrm{C}$ was held for $5 \mathrm{~min}$ and increased by $4^{\circ} \mathrm{C} / \mathrm{min}$ to an end temperature of $240^{\circ} \mathrm{C}$. The detector temperature was $300^{\circ} \mathrm{C}$.

\section{Cell Culture}

Cells (HL-60, U937, and SKOV-3) were grown in culture medium composed of RPMI-1640 with glutamine (13018-031, Gibco, Invitrogen by Life Technology, Taastrup, Denmark), supplemented with $10 \mathrm{mM}$ HEP- 
ES, $23.8 \mathrm{mM} \mathrm{NaHCO}$, $10 \%$ fetal calf serum (FCS; 10270-106, Gibco), $2 \mathrm{~m} M$ Glutamax (Gibco), $60 \mu \mathrm{g}$ of penicillin/mL (Benzylpenicillin, Panpharma, Luitré, France) and $0.1 \mathrm{mg}$ of streptomycin $/ \mathrm{mL}$ (Sigma-Aldrich). The cells were cultured in $75-\mathrm{cm}^{2}$ flasks (90075, Techno Plastic Products, Trasadingen, Switzerland) in a humidified atmosphere with $5 \% \mathrm{CO}_{2}$ at $37^{\circ} \mathrm{C}$. HL-60 and U937 cells were kept at $1 \times 10^{5}$ to $1 \times 10^{6}$ and 1 $\times 10^{5}$ to $2 \times 10^{6}$ cells $/ \mathrm{mL}$, respectively. The SKOV-3 cells were grown to approximately $90 \%$ confluence and split at subculture ratios between $1: 2$ and 1:6, using PBS containing $0.063 \%$ trypsin (wt/vol) and $0.53 \mathrm{mM}$ EDTA to detach the cells.

\section{Measurement of Cytotoxic Activity}

Two assays were used to analyze the cytotoxic activity of the various compounds: an ATP assay estimating cell viability by quantifying the ATP content of the cells through detection of luminescence (counts/s) resulting from an ATP-driven conversion of luciferin to oxiluciferin by luciferase (CellTiter-Glo Luminescent cell viability assay, Promega, Nacka, Sweden) and an assay measuring the release of lactate dehydrogenase (LDH) from the cells (Cytotoxicity Detection Kit ${ }^{\text {PLUS }}$ (LDH), Roche Applied Science, Hvidovre, Denmark). The latter assay gives a measure of the integrity of the plasma membrane, as LDH is only present outside the cells if the integrity of the plasma membrane is lost.

Detached SKOV-3 cells were washed by centrifugation at $150 \times g$ and resuspension in culture medium to achieve $1 \times 10^{5}$ cells $/ \mathrm{mL}$ of medium. One hundred microliters of cell suspension was added to each well $\left(1 \times 10^{4}\right.$ cells/well) of 96-well plates (136101, NUNC, Roskilde, Denmark, for ATP assays and 167008, NUNC, for LDH assays) and cultured for $24 \mathrm{~h}$. Immediately before the addition of the test samples, the cells were washed twice with $100 \mu \mathrm{L}$ of serum-free culture medium per well and $50 \mu \mathrm{L}$ of serum-free culture medium was added. The HL-60 and U937 cells, grown in suspension, were harvested by centrifugation at $150 \times g$ for $5 \mathrm{~min}$, resuspended at $2 \times 10^{5}$ cells $/ \mathrm{mL}$ in serum-free culture medium, and seeded into 96 -well plates with $50 \mu \mathrm{L}$ of cell suspension per well $\left(1 \times 10^{4}\right.$ cells/well $)$. To investigate the influence of cell numbers on cytotoxicity, $1 \times$ $10^{4}, 2 \times 10^{4}$, or $4 \times 10^{4}$ cells/well were used.

Lyophilized $\alpha$-LA was dissolved in PBS before incubation. For investigation of the cytotoxicity of OA alone, $4 \mu \mathrm{L}$ of $\mathrm{OA}$ was dissolved in $40 \mu \mathrm{L}$ of $96 \%$ ethanol and transferred to $1 \mathrm{~mL}$ of PBS $(4 \mathrm{mg} / \mathrm{mL})$ followed by vortexing, and sonication for $3 \times 5$-min, 2 -fold dilutions from approximately $2 \mathrm{mg} / \mathrm{mL}$ to $7.8 \mu \mathrm{g} / \mathrm{mL}$ were subsequently made in PBS. Immediately before addition to the cells, the OA dilutions were sonicated for $5 \mathrm{~min}$. To investigate the effect of simple mixing of $\alpha$-LA and OA, $\alpha$-LA (final concentration, $0.5 \mathrm{mg} / \mathrm{mL}$ ) and 2-fold dilutions of OA were mixed before use. Two-fold dilutions of $\alpha$-LA, BAMLET, and HAMLET in PBS were made from approximately $2 \mathrm{mg} / \mathrm{mL}$ to $7.8 \mu \mathrm{g} / \mathrm{mL}$, and $50 \mu \mathrm{L}$ of each dilution of $\alpha$-LA, BAMLET, HAMLET, OA, $\alpha-\mathrm{LA}+\mathrm{OA}$, or PBS was added to the cell-containing wells (final volume, $100 \mu \mathrm{L} /$ well). As a control, $50 \mu \mathrm{L}$ of PBS and $5 \mu \mathrm{L}$ of lysis solution [Cytotoxicity Detection $\mathrm{Kit}^{\mathrm{PLUS}}$ (LDH), Roche Applied Science] were added to cells in $50 \mu \mathrm{L}$ of culture medium. A control with $50 \mu \mathrm{L}$ of PBS and $50 \mu \mathrm{L}$ of culture medium (no cells) was also included. In all experiments, except for the investigation of kinetics and inhibition by serum, the cells and proteins or OA were incubated for $1 \mathrm{~h}$ in the medium without FCS in a humidified $5 \% \mathrm{CO}_{2}$ atmosphere at $37^{\circ} \mathrm{C}$. After $1 \mathrm{~h}, 5 \mu \mathrm{L}$ of heat-inactivated FCS was added to all of the wells and the experiments were ended, following additional 3.5-h incubation for the ATP assay. The incubation interval for the LDH assay varied between $15 \mathrm{~min}$ to $4.5 \mathrm{~h}$. For the $\mathrm{LDH}$ assays, the absorbance was read at $490 \mathrm{~nm}$, with a reference wavelength at $630 \mathrm{~nm}$ on an ELx800 Universal Microplate Reader (BioTek, Winooski, VT). For ATP assays, the luminescence was detected as counts/s on a VICTOR ${ }^{3} 1420$ Multilabel Counter (PerkinElmer, Skovlunde, Denmark).

\section{Inhibition of BAMLET by Serum and BSA}

This experiment was performed with HL-60 cells as described above, using the ATP assay with the following modifications: at time $t=0$ the HL-60 cells were suspended in intervals of 0 to $40 \%$ heat-treated FCS (10270-106, Gibco) and 0 to $5.0 \mathrm{mg}$ of $\mathrm{BSA} / \mathrm{mL}$ (A4503, Sigma-Aldrich), respectively, supplemented with various concentrations of BAMLET in the 0.008 to 2.0 $\mathrm{mg} / \mathrm{mL}$ range.

\section{Kinetics of BAMLET Cytotoxicity}

The experiment was performed as described above for HL-60 cells, using the LDH assay with the following modifications: BAMLET was added to HL-60 cells at times $t_{1}=0 \mathrm{~h}, t_{2}=21 / 2 \mathrm{~h}, t_{3}=3.5 \mathrm{~h}, t_{4}=4 \mathrm{~h}$, and $t_{5}=4.25 \mathrm{~h}$, and the experiment was terminated after a total incubation time of $4.5 \mathrm{~h}$. No FCS was added to the cells in these experiments.

\section{RESULTS}

\section{Purification of $\alpha-L A$ by Two-Step Anion Chromatography}

The whey fraction of fresh bovine milk or frozen human milk was subjected to 2 consecutive passages 




Figure 1. An SDS-PAGE analysis of $\alpha-L A$ and bovine alphalactalbumin made lethal to tumor cells (BAMLET). Bovine $\alpha$-LA (lanes 1 and 2) and BAMLET (lanes 3 and 4 ) were examined by SDSPAGE. Lanes 1 and 3 show non-reduced samples, whereas lanes 2 and 4 show samples analyzed after reduction with dithiothreitol followed by iodoacetamide treatment. Molecular weight markers in kilodaltons are shown on the right-hand side (161-0374, Precision Plus Protein Standard, Bio-Rad Laboratories, Copenhagen, Denmark). Samples were separated by SDS-PAGE on $18 \%$ polyacrylamide gels, and the proteins were stained with Coomassie Blue.

through anion exchange columns with and without calcium, respectively. Removing calcium causes changes in structure and charge of $\alpha-L A$, resulting in a longer retention time of $\alpha-\mathrm{LA}$ on the second anion exchange column. As a result, $\alpha-\mathrm{LA}$ and co-eluted impurities from the first column are separated during elution of the second column. From $1 \mathrm{~L}$ of bovine milk, $420 \mathrm{mg}$ of apo $\alpha$-LA was obtained, corresponding to a yield of approximately $35 \%$. The purity of the product is illustrated in Figure 1.

\section{Generation of Complexes Between OA and $\alpha-L A$}

To convert the purified $\alpha$-LA into the $\alpha$-LA:OA complex, an OA conditioned anion exchange column was prepared. DEAE Sepharose and OA were incubated with thorough mixing and sonication, followed by preparation of the column. Excess OA was removed by washing with buffer containing $1 \mathrm{M} \mathrm{NaCl}$. After equilibration with a low ionic strength buffer, EDTA-treated $\alpha$-LA was loaded onto the column. Removal of excess $\alpha$-LA through washing with $0.2 \mathrm{M} \mathrm{NaCl}$ was followed by elution of HAMLET or BAMLET with $1 \mathrm{M} \mathrm{NaCl}$. From $70 \mathrm{mg}$ of bovine apo $\alpha$-LA, approximately $65 \mathrm{mg}$ of BAMLET was obtained. The recoveries of HAMLET made from human $\alpha$-LA gave a similarly high yield. The final $\alpha$-LA:OA ratio was seen to differ between preparations ranging from 1:4 to 1:15, even though the $\alpha$-LA:OA ratio used as starting conditions was 1:20 for all preparations. The final $\alpha$-LA:OA ratio was $1: 10$ for BAMLET and 1:13 for HAMLET in the preparations used in this report.

The SDS-PAGE analysis of $\alpha-\mathrm{LA}$ and BAMLET are shown in Figure 1. Purified $\alpha-\mathrm{LA}$ is seen as a single band around $14 \mathrm{kDa}$ under both reducing and nonreducing conditions (lanes $1+2$ ). The preparation of BAMLET from $\alpha$-LA results in the introduction of higher molecular weight forms above $14 \mathrm{kDa}$. Lane 3 shows non-reduced BAMLET with bands around 14, 25 , and $40 \mathrm{kDa}$ and faint bands with higher molecular weights. Under reducing conditions, only bands at 14 and $25 \mathrm{kDa}$ can be seen (lane 4). Western blotting using affinity purified anti- $\alpha-\mathrm{LA}$ antibodies showed that all the bands contained $\alpha$-LA, and N-terminal sequence analysis detected only $\alpha$-LA (data not shown). Thus, it seems likely that the higher molecular weight bands represent dimers $(28 \mathrm{kDa})$, trimers $(42 \mathrm{kDa})$, and higher oligomeric forms of $\alpha-\mathrm{LA}$.

\section{Cytotoxicity of BAMLET}

To compare the cytotoxic activity of the bovine $\alpha$-LA:OA preparation and the constituents from which the complex originated, cells were treated with BAMLET, a simple mixture of $\alpha-\mathrm{LA}$ and OA, or with each constituent alone. The cells were exposed to the different components for $1 \mathrm{~h}$ under serum-free conditions, followed by incubation for $3.5 \mathrm{~h}$ in the presence of $5 \%$ heat-treated FCS. In one assay, LDH, which is a cytoplasmic enzyme normally found only inside the cells, was measured in the cell-culture medium. Leakage of LDH into the cell-culture medium indicates damage to the plasma membrane and was used as an indicator of cell death. In a second assay, the ATP content was used as an estimate of the number of living cells, as ATP is rapidly hydrolyzed and not regenerated in damaged or metabolically inactive cells. Loss of viability was quantified as increase in LDH leakage or decrease in ATP level as compared with PBS-treated controls.

Figure 2 presents the cytotoxic effect of BAMLET, $\alpha-\mathrm{LA}, \mathrm{OA}$, and a mixture of $\alpha-\mathrm{LA}$ and $\mathrm{OA}$ on the promyeloid cancer cell line, HL-60. $\alpha$-Lactalbumin on its own did not exert a cytotoxic effect in any of the concentrations tested. In contrast, a cytotoxic effect of BAMLET could be seen with half of the cells dead $\left(\mathbf{L C}_{50}\right)$ at $32 \mu \mathrm{g} / \mathrm{mL}$ (Figure $\left.2 \mathrm{~A}\right)$. Figure $2 \mathrm{~B}$ shows the cytotoxic effect of $\mathrm{OA}$ alone and of a mixture of $\mathrm{OA}$ and $\alpha$-LA as compared with BAMLET. In Figure 2B, 
A

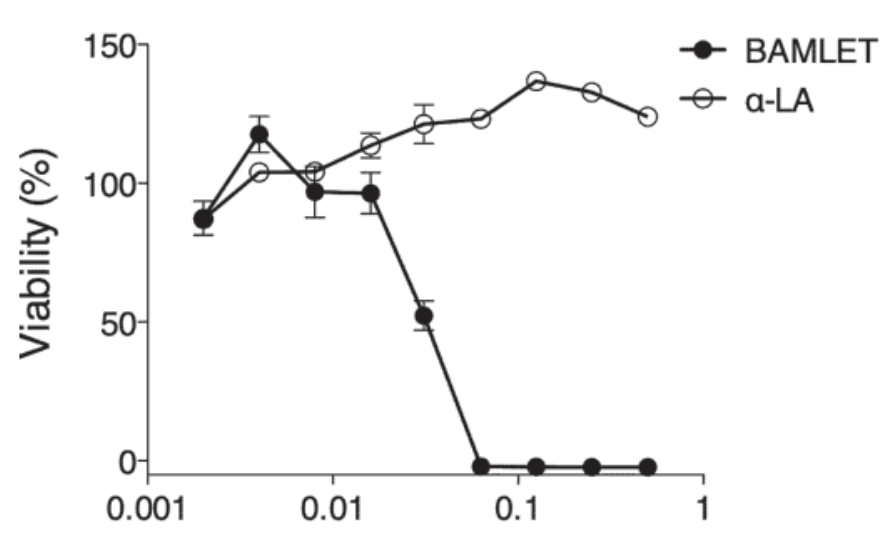

Protein $(\mathrm{mg} / \mathrm{mL})$



Figure 2. Cytotoxicity of bovine alpha-lactalbumin made lethal to tumor cells (BAMLET), $\alpha$-LA, and oleic acid (OA) on HL-60 cells. The effect of BAMLET, $\alpha-\mathrm{LA}$, and OA on HL-60 cells was measured by the ATP assay after $4.5 \mathrm{~h}$ of incubation. A) Cytotoxicity of $\alpha$-LA and BAMLET. B) Cytotoxicity of BAMLET, OA, and OA mixed with $\alpha$-LA. The content of OA in the BAMLET preparation was measured (BAMLET: $\alpha$-LA:OA ratio $=1: 10$ ) and plotted on the $\mathrm{x}$-axis in $\mathrm{B}$, whereas the protein content is plotted on the $\mathrm{x}$-axis in A. Viability was calculated from the ATP content (measured as luminescence) of test sample-treated cells expressed as percentage of controls: [(test sampletreated cells - detergent-lysed cells)/(PBS-treated cells - detergentlysed cells)] $\times 100 \%$. The experiment was performed in triplicate, and the range and mean are shown for each point.

the OA content is indicated on the $\mathrm{x}$-axis, whereas the $\alpha$-LA content is indicated on the $\mathrm{x}$-axis in Figure $2 \mathrm{~A}$. Oleic acid alone was toxic to the cells $\left(\mathrm{LC}_{50}: 90 \mu \mathrm{g}\right.$ of $\mathrm{OA} / \mathrm{mL}$ ). The simple mixing of OA with $\alpha$-LA did not have an additional effect in comparison with treatment with OA alone. However, when incorporated in BAMLET, OA equivalent to one-fifteenth of OA alone was enough to induce cytotoxicity $\left(\mathrm{LC}_{50}: 6 \mu \mathrm{g}\right.$ of $\left.\mathrm{OA} / \mathrm{mL}\right)$. Because OA was dissolved in ethanol and mixed with

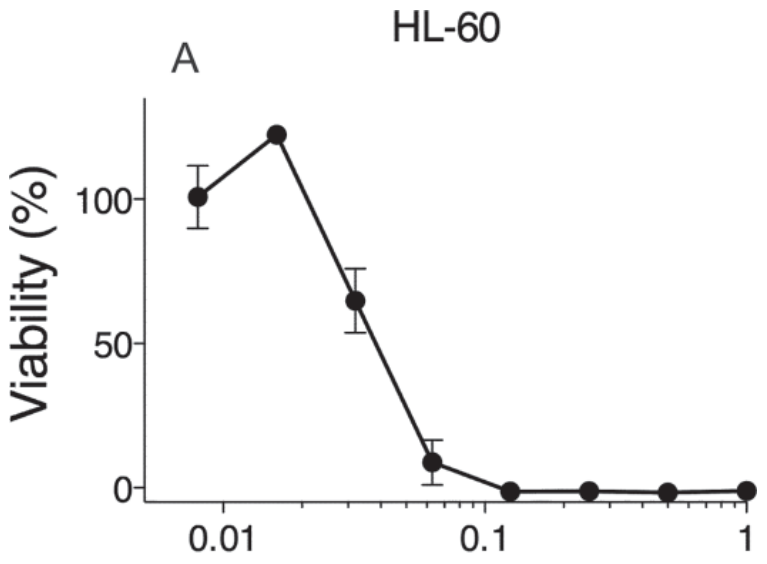

B

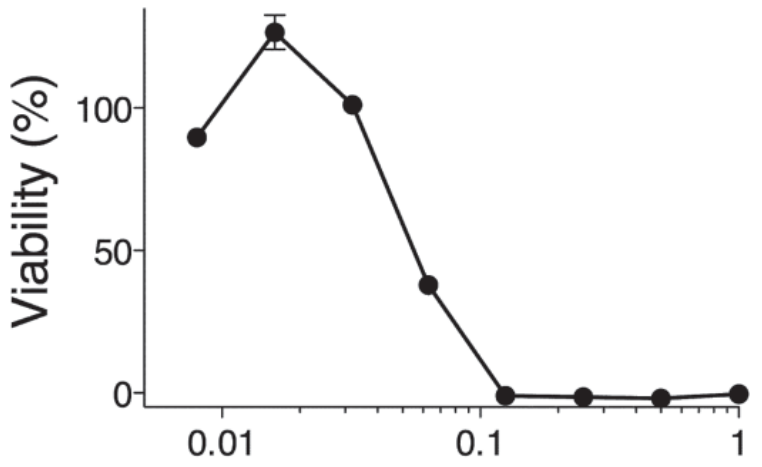

C

SKOV-3

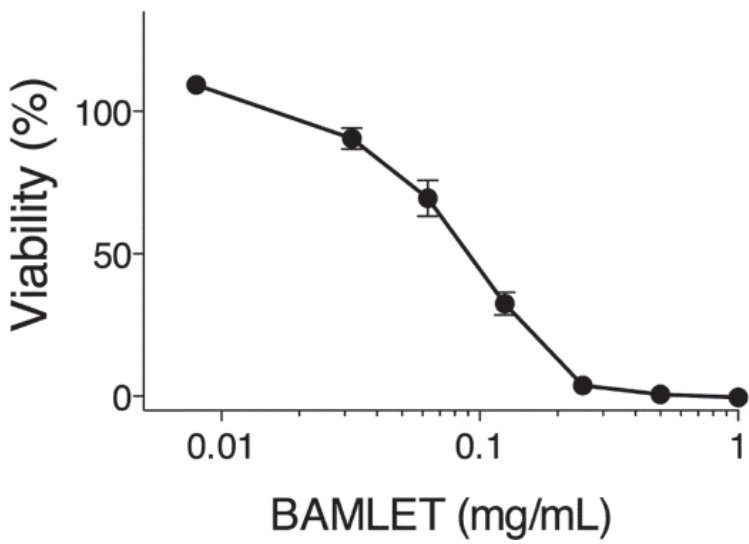

Figure 3. The effect of bovine alpha-lactalbumin made lethal to tumor cells (BAMLET) on viability of different cell lines. Cells from each cell line were incubated with BAMLET for $4.5 \mathrm{~h}$ before termination of the experiments with the ATP assay. A representative experiment is shown for each cell line: A) HL-60 cells, B) U937 cells, C) SKOV-3 cells. Viability was calculated from the ATP content (measured as luminescence) of test sample-treated cells expressed as percentage of controls: [(test sample-treated cells - detergent-lysed cells) $/($ PBS-treated cells - detergent-lysed cells) $] \times 100 \%$. The experiments were performed in duplicate, and the range and mean are shown for each point. 

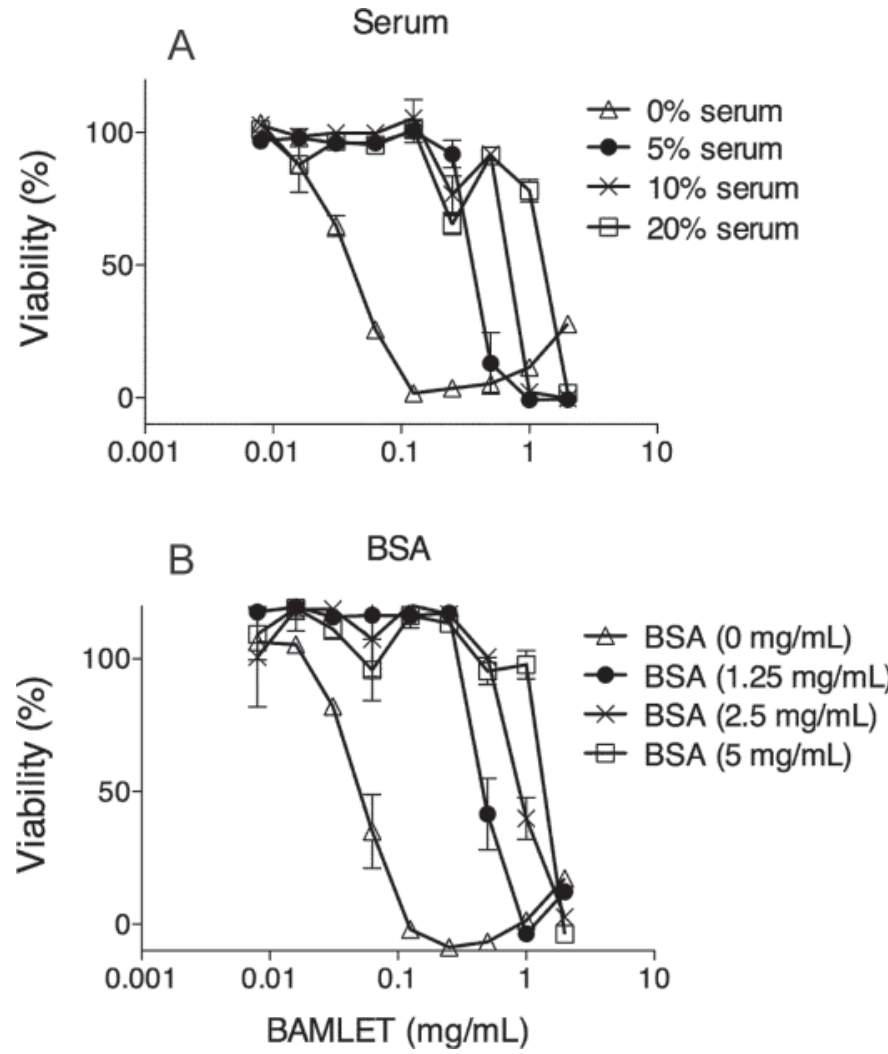

Figure 4. Inhibition of bovine alpha-lactalbumin made lethal to tumor cells (BAMLET) cytotoxicity by serum and BSA. The BAMLET was added to HL-60 cells in media with increasing concentrations of fetal calf serum (FCS; A) or BSA (B). The experiment was terminated after $4.5 \mathrm{~h}$ of incubation with the ATP assay. The concentrations of BSA used were calculated to match the amount of BSA present in $5 \%, 10 \%$, and $20 \%$ serum (25 $\mathrm{mg}$ of BSA $/ \mathrm{mL}$ of serum). Viability was calculated from the ATP content (measured as luminescence) of test sample-treated cells expressed as percentage of controls: [(test sampletreated cells - detergent-lysed cells)/(PBS-treated cells - detergentlysed cells) $] \times 100 \%$. The experiments were performed in duplicate, and the range and mean are shown for each point.

PBS before addition to the cells, the cytotoxicity of ethanol was tested. The maximum final concentration of ethanol used (1\%) did not affect cell survival under the experimental conditions chosen (data not shown).

The cytotoxicity of BAMLET on different cell types was investigated. Figure 3 shows how the sensitivity to BAMLET treatment differs between the cell lines examined, with $\mathrm{LC}_{50}$ values of 40,55 , and $90 \mu \mathrm{g} / \mathrm{mL}$ for HL-60, U937, and SKOV-3 cells, respectively. It follows that the adherent cell line was less sensitive to BAMLET as compared with the 2 cell lines growing in suspension, HL-60 being the most sensitive of them.

\section{Inhibition of BAMLET Cytotoxicity by Serum}

Investigation by C. Svanborg and colleagues has routinely been done on the cytotoxicity of HAMLET at serum-free conditions during the first hour of incubation, followed by addition of $5 \%$ serum for the remaining incubation time (Aits et al., 2009). To investigate the influence of FCS or BSA on the cytotoxicity of BAMLET, HL-60 cells were treated with BAMLET in the presence of increasing concentrations of FCS or BSA. The chosen concentrations of BSA tested were comparable to the amount of BSA present in the tested dilutions of FCS (according to the manufacturer, 1 $\mathrm{mL}$ of the used FCS contains approximately $25 \mathrm{mg}$ of BSA). As seen in Figure 4, the cytotoxicity of BAMLET was markedly inhibited by the presence of either FCS or BSA. At increasing BAMLET concentrations, higher concentrations of serum were needed for inhibition. Proportionality in the inhibitory effect of BSA was noticed, as full inhibition of $250 \mu \mathrm{g}$ of BAMLET/ $\mathrm{mL}$ was obtained with $1.25 \mathrm{mg}$ of $\mathrm{BSA} / \mathrm{mL}$, and the activity of $500 \mu \mathrm{g}$ of BAMLET $/ \mathrm{mL}$ was quenched with $2.5 \mathrm{mg}$ of $\mathrm{BSA} / \mathrm{mL}$.

\section{Kinetics of BAMLET-Induced Cytotoxicity}

The sensitivity (i.e., the quantity of BAMLET needed to reach half of the maximal response), was found to be similar for the 2 cytotoxicity assays (measuring LDH and ATP). However, because the LDH assay performed better with short-term handling of samples and lysis controls, we chose to use the LDH leakage assay to estimate the kinetics of BAMLET-induced cytotoxic action. As shown in Figure 5, the cytotoxic effect of BAMLET was dependent on both incubation time and concentration. Within the maximal incubation time of $4.5 \mathrm{~h}$, BAMLET concentrations of $63 \mu \mathrm{g} / \mathrm{mL}$ or higher reached $50 \%$ of the maximal LDH release. Concentrations of 125 and $63 \mu \mathrm{g}$ of BAMLET $/ \mathrm{mL}$ were sufficient to induce $50 \% \mathrm{LDH}$ release, following $30 \mathrm{~min}$ and $2 \mathrm{~h}$ incubation, respectively. At BAMLET concentrations of $250 \mu \mathrm{g} / \mathrm{mL}$ or higher, $50 \%$ of the maximal LDH release was reached within just 15 min, and BAMLET concentrations above $500 \mu \mathrm{g} / \mathrm{mL}$ resulted in almost $100 \% \mathrm{LDH}$ release within the same time span.

\section{The Influence of Cell Number on BAMLET Cytotoxicity}

The ratio between the number of cells and the concentration of BAMLET needed to induce killing proved to be important. The results obtained following 4.5-h BAMLET treatment of $2 \times 10^{5}, 4 \times 10^{5}$, or $8 \times 10^{5}$ cells/mL are presented in Figure 6. A 2-fold increase in cell number was found to require a 2 -fold increase in concentration of BAMLET needed to kill all cells. To visualize this, the amount of BAMLET per $2 \times 10^{5}$ 
2166

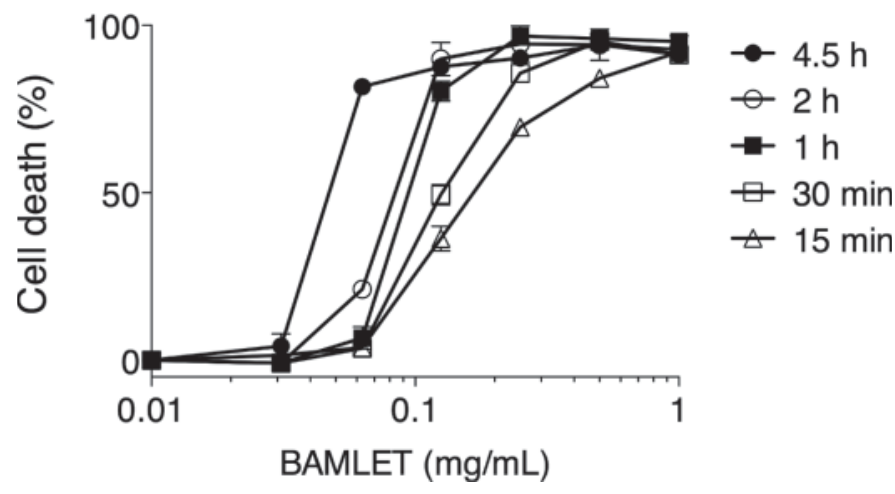

Figure 5. Kinetics of bovine alpha-lactalbumin made lethal to tumor cells (BAMLET)-induced cytotoxicity. The kinetics of BAMLETinduced cytotoxicity on HL-60 cells was studied using the LDH release assay. The time given at the symbols is the time from addition of BAMLET to termination of the experiment with the lactate dehydrogenase (LDH) assay. To each time point, 6 different BAMLET concentrations were added in duplicate. Cell death induced by BAMLET was calculated as LDH leakage (measured at 490/630 nm) expressed as percentage of controls: $\left[\left(\mathrm{A}_{490 / 630} \mathrm{BAMLET}\right.\right.$-treated cells $-\mathrm{A}_{490 / 630}$ PBS-treated cells $) /\left(\mathrm{A}_{490 / 630}\right.$ detergent-lysed cells $-\mathrm{A}_{490 / 630} \mathrm{PBS}-$ treated cells) $] \times 100 \%$. The range and mean are shown for each point.

cells is depicted on the $\mathrm{x}$-axis in Figure 6B, resulting in convergence of the dose-response curves.

\section{Comparison of HAMLET and BAMLET Prepared by Different Procedures}

To determine whether differences in the preparation procedures or the species of origin of $\alpha$-LA used affect the cytotoxicity of the complex, 4 different preparations of $\alpha$-LA:OA complexes were compared: HAMLET and BAMLET prepared by the new method described in this paper (called HAMLET and BAMLET), and HAMLET and BAMLET prepared by the conventional method (Svensson et al., 2000; called HAMLET-conventional and BAMLET-conventional). The cytotoxicity of the 4 preparations was tested on 3 cancer cell lines (HL-60, U937, and SKOV-3). The cell lines exhibited different sensitivity toward the $4 \alpha$-LA:OA preparations (Figure 7). In all cell lines, HAMLET was found to be the most potent cytotoxic agent, whereas HAMLET-conventional, in our hands, was the least active. The cytotoxicities of BAMLET and BAMLET-conventional were very similar and intermediate between the cytotoxicities of HAMLET and HAMLET-conventional. The HL-60 cells were consistently the most sensitive toward the $\alpha-\mathrm{LA}: \mathrm{OA}$ preparations, and the $\mathrm{LD}_{50}$ values were estimated to be approximately $28,41,45$, and $74 \mu \mathrm{g} / \mathrm{mL}$ for the HAMLET, BAMLET, BAMLET-conventional, and HAMLET-conventional preparations, respectively. In the same order of appearance, the $\mathrm{LD}_{50}$ values were $41,58,58$, and $80 \mu \mathrm{g} / \mathrm{mL}$ and $80,96,99$, and $170 \mu \mathrm{g} /$ $\mathrm{mL}$ in the U937 and SKOV-3 cells, respectively. The data indicate that, overall, the SKOV-3 cells were the most resistant to cell death induced by either of the $\alpha$-LA:OA preparations. The $\alpha$-LA:OA ratios of the 4 preparations, HAMLET-conventional, BAMLETconventional, HAMLET and BAMLET were 1:4, 1:5, $1: 13$, and $1: 10$, respectively.

\section{DISCUSSION}

Most studies of the cell-regulating activity of $\alpha$-LA have been performed on the human protein (Svanborg et al., 2003; Mok et al., 2007), but some information about bovine material has been presented. Already in 1992, Thompson et al. (1992) published data of a mammary growth inhibitor factor isolated from human, cow, goat, and camel milk and showed that the protein was $\alpha$-LA. Cell division of normal mammary epithelial cells was inhibited at a concentration of $10 \mathrm{ng} / \mathrm{mL}$, whereas normal fibroblasts from the same tissue did not respond to the protein. Other work has shown regulation of cell growth by $\alpha$-LA in concentrations of 5 to $35 \mu \mathrm{g} / \mathrm{mL}$ (Sternhagen and Allen, 2001), and using different commercial preparations of bovine $\alpha$-LA on an intestinal cell line, cytotoxic activity was found in some of the samples at higher concentrations (Xu et al., 2005a). Furthermore, bovine monomeric $\alpha$-LA incubated in a buffer containing trifluoroethanol for $5 \mathrm{~d}$ resulted in formation of SDS-PAGE-stable multimers with acquired cytotoxic activity (Xu et al., 2005b). By affinity chromatography on an anti- $\alpha$-LA antibody column, a preparation of higher molecular weight forms of $\alpha-\mathrm{LA}$ has been obtained, which exhibited potent inhibition of cell growth (Xu et al., 2005b).

The existence of molten globule structures for $\alpha$-LA has been investigated extensively and such forms can be generated at several conditions, including low $\mathrm{pH}$ or the absence of calcium (Kuwajima, 1996). In the presented purification protocol, we have exploited the observation that apo $\alpha$-LA has a stronger binding affinity for DEAE agarose as compared with the calciumassociated form of the protein and an even stronger affinity when the column contained OA. The eluted complex was a mixture of $\mathrm{OA}$ and $\alpha-\mathrm{LA}$ in varying proportions ranging from 5 to 15 molar excess of fatty acid as compared with protein. This seems to indicate that different forms of complexes or aggregates might exist. However, at present, it is not clear exactly which molecular structures represent the cytotoxic form of the protein/fatty acid complex.

Our preparation method of HAMLET and BAMLET differs from the conventional method in several aspects. Both methods exploit the calcium-binding property of $\alpha$-LA in the purification of $\alpha$-LA. However, whereas the conventional procedure uses one-step hydrophobic 
A
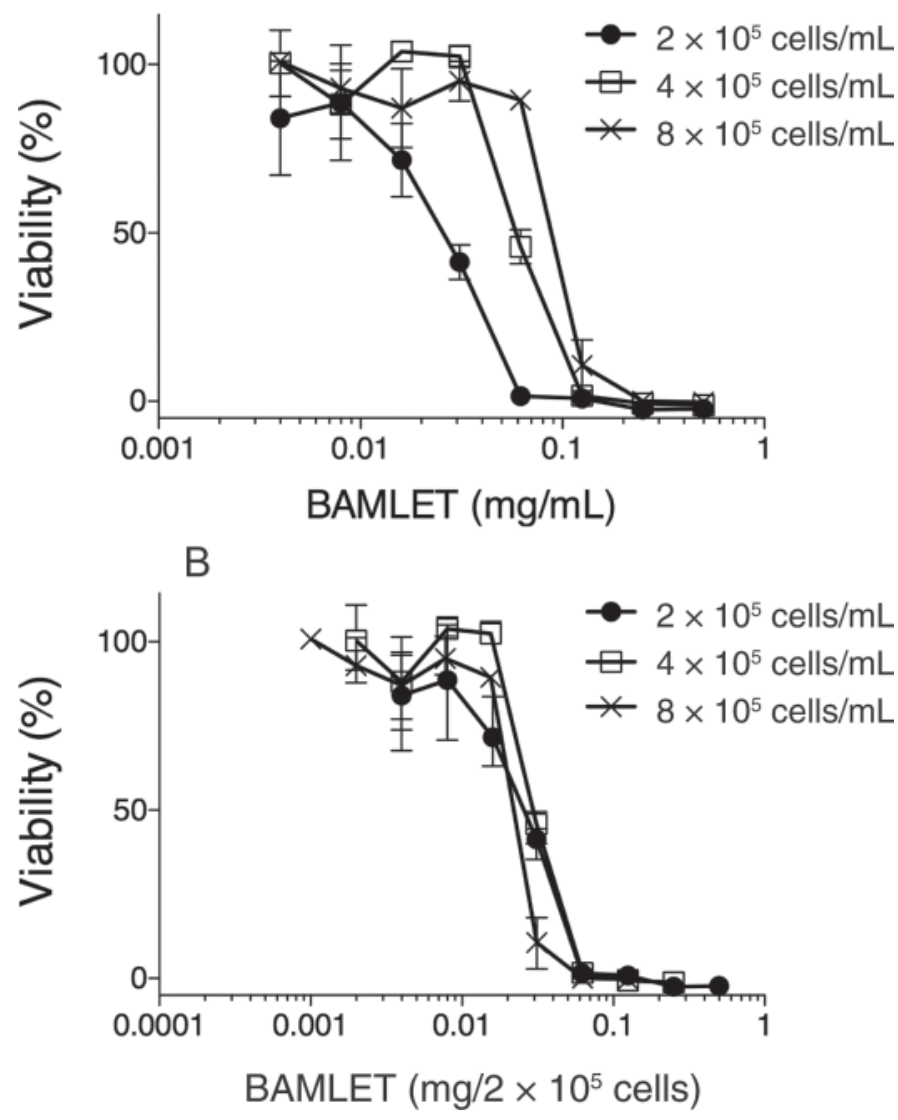

Figure 6. Bovine alpha-lactalbumin made lethal to tumor cells (BAMLET) cytotoxicity on different densities of HL-60 cells. A) BAMLET cytotoxicity investigated by the ATP assay on $2 \times 10^{5}, 4 \times$ $10^{5}$, or $8 \times 10^{5} \mathrm{HL}-60$ cells $/ \mathrm{mL}$ with $50 \mu \mathrm{L} /$ well after $4.5 \mathrm{~h}$ of incubation. B) Alternative graphic presentation of the data from A, where the amount of BAMLET per $2 \times 10^{5}$ cells from the wells with cell suspension of $2 \times 10^{5}, 4 \times 10^{5}$, or $8 \times 10^{5}$ cells $/ \mathrm{mL}$ is plotted on the $\mathrm{x}$-axis. Viability was calculated from the ATP content (measured as luminescence) of test sample-treated cells expressed as percentage of controls: [(test sample-treated cells - detergent-lysed cells)/(PBS-treated cells - detergent-lysed cells) $] \times 100 \%$. The experiment was performed in triplicate, and the range and mean are shown for each point.

interaction chromatography, the present method uses 2 consecutive ion exchange chromatography columns. The main differences between the procedures for conversion of $\alpha$-LA to the cytotoxic complexes relate to the matrix material (i.e., DEAE Trisacryl M versus DEAE Sepharose). Moreover, in the conventional procedure, the column is conditioned with OA by loading with an OA-containing buffer, whereas the present procedure ensures a more thorough dispersion of OA throughout the column by mixing the OA and matrix material before packing the column.

Despite the above-mentioned differences, cytotoxic complexes are formed by both methods. It has been claimed that simple mixing of $\alpha$-LA and OA, followed by heat treatment, $\mathrm{pH}$ changes, or incubation at RT, can produce a cytotoxic complex (Kamijima et al., 2008; Knyazeva et al., 2008; Zhang et al., 2009; Tolin et al., 2010), which suggests that the exact preparation method is not crucial. As mentioned above, several examples of the cytotoxicity of $\alpha$-LA in the absence of OA have also been reported (Thompson et al., 1992; Sternhagen and Allen, 2001, Xu et al., 2005a,b; Lin et al., 2008). Our preparations of highly purified $\alpha$-LA did not show any cytotoxic activity (Figure 2). However, we did see cytotoxic activity of OA in the absence of $\alpha$-LA. Nevertheless, the OA concentration required to kill the cells appeared to be 15-fold higher for OA alone than for OA present in BAMLET. It should be noted, though, that the actual concentration of fatty acid added to the cells may be lower than calculated due to low solubility and loss of fatty acid while handling. We did not see any enhanced cytotoxic effect of a simple mixture of $\alpha$-LA and OA as compared with OA alone. Nevertheless, this implies that whatever procedure is used, the cytotoxic activity of OA alone must be taken into account. The BAMLET we have produced exhibited cytotoxicity toward cell types originating from different tissues and types of cancer, which is also the case for HAMLET produced by the conventional method (Svanborg et al., 2003).

The specific activity of BAMLET expressed as the concentration of $\alpha-\mathrm{LA}$ in the $\alpha$-LA:OA complex, which decreases cell viability by $50 \%$ in a given cell line, differed little between the different preparations, despite some variation in the relative OA content. A consistent finding was that the titration curve was very steep (i.e., only a 4-fold dilution would decrease the observed killing of the target cells from about $100 \%$ to negligible). This obviously complicates the study of these complexes, as many dilutions of the preparations are needed to obtain proper dose-response curves. In addition, as shown in Figure 6 , the concentration of BAMLET required to induce killing is highly dependent on cell number.

We found that our modifications resulted in high yields of a product with a specific cytotoxicity comparable to that for HAMLET as already described (Svensson et al., 2000). Comparison of the cytotoxic activity of HAMLET and BAMLET prepared by the conventional or the alternative method thus revealed only minor differences in HAMLET cytotoxicity, and the cytotoxicity profiles of the 2 BAMLET preparations were very similar. The $\alpha$-LA:OA ratio of the HAMLET and BAMLET complexes prepared by the conventional method (1:4-1:8) was consistent with ratios presented in the literature (Pettersson-Kastberg et al., 2009), whereas the OA content found in the HAMLET and BAMLET complexes prepared by the alternative 

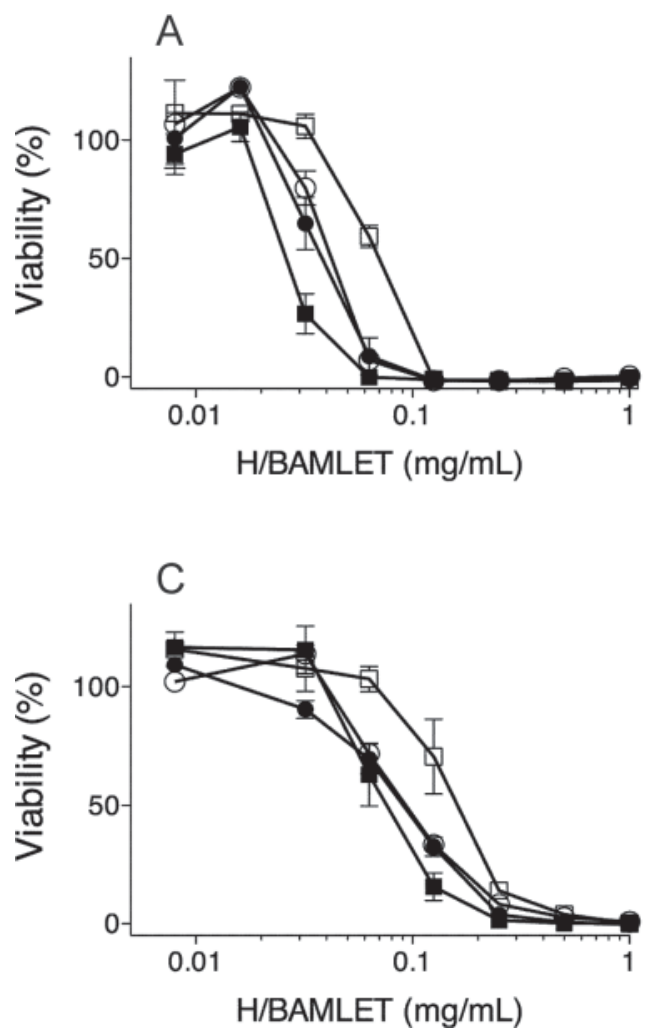


Figure 7. Comparison of the cytotoxicity of $\mathrm{H}$ /bovine alpha-lactalbumin made lethal to tumor cells (BAMLET) and H/BAMLETconventional. The cells were incubated with the different human alpha-lactalbumin made lethal to tumor cells (HAMLET) and BAMLET preparations for $4.5 \mathrm{~h}$ before termination of the experiments with the ATP assay. A representative experiment is shown for each cell line: A) HL-60 cells, B) U937 cells, C) SKOV-3 cells. Viability was calculated from the ATP content (measured as luminescence) of test sample-treated cells expressed as percentage of controls: [(test sample-treated cells - detergent-lysed cells)/(PBS-treated cells - detergent-lysed cells)] $\times 100 \%$. The experiments were performed in duplicate, and the range and mean are shown for each point.

method (1:10-1:13) was somewhat higher. It is possible that some of the OA is not directly bound to $\alpha$-LA but present in some form of aggregate.

The binding of OA to $\alpha$-LA in HAMLET was originally thought to be at a 1:1 ratio with a proposed OA binding site between the $\alpha$-helical and the $\beta$ sheet domain (Svensson et al., 2003b). This specific binding of OA to $\alpha$-LA in HAMLET was supported by the finding that only the cis fatty acids OA and vaccenic acid could convert apo- $\alpha$-LA to the cytotoxic variant (Svensson et al., 2003b). However, it is not known in which manner as many as 10 or more OA molecules can be associated with $\alpha$-LA.

Apoptosis or apoptosis-like cell death has previously been proposed as the major cytotoxic effectormechanism (Hallgren et al., 2006, 2008). Rammer et al. (2010) have recently shown that BAMLET rapidly enters cancer cells and accumulates in the endolysosomal compartment, where it induces a lysosomal deathpathway through leakage of lysosomal cathepsins into the cytosol (Rammer et al., 2010). In the present study,
BAMLET-induced cell death was observed after 15 min. This rapid response, measured as LDH release, could suggest that permeabilization of the plasma membrane may play a role in the induction of cell death, at least in high concentrations.

Serum appears to have a neutralizing effect on the cytotoxic activity of HAMLET. Most experiments published to date by C. Svanborg and colleagues were carried out by incubating the cells with HAMLET in serum-free medium for the first 30 to $60 \mathrm{~min}$, followed by further incubation in the presence of FCS (Svensson et al., 2000, 2003a,b; Aits et al., 2009). Experiments conducted by Köhler et al. (2001) showed that BSA decreased mitochondrial swelling and delayed the loss of mitochondrial membrane potential $(\Delta \Psi \mathrm{m})$ of HAMLET-treated isolated mitochondria. Mossberg et al. (2007) state that serum albumin, by virtue of its fatty acid binding capacity, binds and removes OA from HAMLET, rendering it inactive. We examined the effect of adding FCS or BSA to the $\alpha$-LA:OA complex and observed progressive inhibition with increasing con- 
centrations of both FCS and BSA, suggesting that the neutralizing capacity of FCS can indeed be explained by its albumin content.

A complex between $\alpha-\mathrm{LA}$ and OA has been tested as a potential anticancer agent on humans and rats (Fischer et al., 2004; Mossberg et al., 2007). However, as discussed above, the cytotoxic activity of the $\alpha-\mathrm{LA}: \mathrm{OA}$ complex is inhibited by serum and serum albumin, and until this neutralization is overcome, the complex can only be used at sites where serum albumin is not accessible. Although this clearly hampers the potential uses of the complex, topical application of HAMLET has shown promise in the treatment of papillomas (Gustafsson et al., 2004) and also against bladder cancer (Mossberg et al., 2007). For such applications, one could anticipate that the bovine equivalent, BAMLET, might be used instead of the human complex. It would greatly rationalize production and be more cost effective, if bovine milk was used as the source of $\alpha$-LA.

Each year, the global production of bovine milk is in the order of 700 million tonnes (FAO, 2007), containing about 0.8 million tonnes of $\alpha-\mathrm{LA}$, which are mainly consumed by humans, either as dairy products or as ingredients added to other food categories. Little is known about the amount of BAMLET-like activity that might be generated in different kinds of foods containing $\alpha$-LA. Obviously, OA and other fatty acids will be present in most food, either as triglycerides or as FFA formed during digestion of food. As a first step to get more knowledge of this potentially important nutritional aspect, the presented simple protocol describes the production of BAMLET with high cytotoxic activity toward cancer cells measured in in vitro assays, with a similar activity to that of the material produced from human milk.

\section{ACKNOWLEDGMENTS}

We thank Catharina Svanborg [Department of Microbiology, Immunology and Glycobiology (MIG), Institute of Laboratory Medicine, Lund University, Sweden] for allowing us to prepare BAMLET-conventional using her laboratory facilities and for providing HAMLETconventional, and Ann-Kristin Mossberg (MIG, Institute of Laboratory Medicine, Lund University, Sweden] for excellent laboratory assistance during the preparation of BAMLET-conventional in Lund. We also thank Margit Skriver Rasmussen (The Protein Chemistry Laboratory, Department of Molecular Biology, Aarhus University, Denmark) for help and advice during the preparation of HAMLET and BAMLET.

\section{REFERENCES}

Aits, S., L. Gustafsson, O. Hallgren, P. Brest, M. Gustafsson, M. Trulsson, A. K. Mossberg, H. U. Simon, B. Mograbi, and C. Svan- borg. 2009. HAMLET (human alpha-lactalbumin made lethal to tumor cells) triggers autophagic tumor cell death. Int. J. Cancer 124:1008-1019.

FAO. 2007. Statistics. Accessed June 1, 2010. http://faostat.fao.org/ site/339/default.aspx.

Fischer, W., L. Gustafsson, A.-K. Mossberg, J. Gronli, S. Mork, R. Bjerkvig, and C. Svanborg. 2004. Human $\alpha$-lactalbumin made lethal to tumor cells (HAMLET) kills human glioblastoma cells in brain xenografts by an apoptosis-like mechanism and prolongs survival. Cancer Res. 64:2105-2112.

Fox, P. F. 1998. Dairy Chemistry and Biochemistry. Blackie Academic \& Professional, London, UK.

Gustafsson, L., I. Leijonhufvud, A. Aronsson, A.-K. Mossberg, and C. Svanborg. 2004. Treatment of skin papillomas with topical $\alpha$-lactalbumin-oleic acid. N. Engl. J. Med. 350:2663-2672.

Håkansson, A., B. Zhivotovsky, S. Orrenius, H. Sabharwal, and C. Svanborg. 1995. Apoptosis induced by a human milk protein. Proc. Natl. Acad. Sci. USA 92:8064-8068.

Hallgren, O., S. Aits, P. Brest, L. Gustafsson, A.-K. Mossberg, B. Wullt, and C. Svanborg. 2008. Apoptosis and tumor cell death in response to HAMLET (human $\alpha$-lactalbumin made lethal to tumor cells). Adv. Exp. Med. Biol. 606:217-240.

Hallgren, O., L. Gustafsson, H. Irjala, G. Selivanova, S. Orrenius, and C. Svanborg. 2006. HAMLET triggers apoptosis but tumor cell death is independent of caspases, Bcl-2 and p53. Apoptosis 11:221-233.

Kamijima, T., A. Ohmura, T. Sato, K. Akimoto, M. Itabashi, M. Mizuguchi, M. Kamiya, T. Kikukawa, T. Aizawa, M. Takahashi, K. Kawano, and M. Demura. 2008. Heat-treatment method for producing fatty acid-bound alpha-lactalbumin that induces tumor cell death. Biochem. Biophys. Res. Commun. 376:211-214.

Knyazeva, E. L., V. M. Grishchenko, R. S. Fadeev, V. S. Akatov, S. E. Permyakov, and E. A. Permyakov. 2008. Who Is Mr. HAMLET? Interaction of Human $\alpha$-Lactalbumin with Monomeric Oleic Acid. Biochemistry 47:13127-13137.

Köhler, C., V. Gogvadze, A. Håkansson, C. Svanborg, S. Orrenius, and B. Zhivotovsky. 2001. A folding variant of human $\alpha$-lactalbumin induces mitochondrial permeability transition in isolated mitochondria. Eur. J. Biochem. 268:186-191.

Kronman, M. J., S. K. Sinha, and K. Brew. 1981. Characteristics of the binding of $\mathrm{Ca}^{2+}$ and other divalent metal ions to bovine $\alpha$-lactalbumin. J. Biol. Chem. 256:8582-8587.

Kuwajima, K. 1996. The molten globule state of $\alpha$-lactalbumin. FASEB J. 10:102-109.

Lin, I. C., S. L. Su, and C. D. Kuo. 2008. Induction of cell death in RAW 264.7 cells by alpha-lactalbumin. Food Chem. Toxicol. $46: 842-853$.

Lindahl, L., and H. J. Vogel. 1984. Metal-ion-dependent hydrophobicinteraction chromatography of alpha-lactalbumins. Anal. Biochem. 140:394-402.

Mok, K. H., J. Pettersson, S. Orrenius, and C. Svanborg. 2007. HAMLET, protein folding, and tumor cell death. Biochem. Biophys. Res. Commun. 354:1-7.

Mossberg, A. K., B. Wullt, L. Gustafsson, W. Månsson, E. Ljunggren and C. Svanborg. 2007. Bladder cancers respond to intravesical instillation of HAMLET (human $\alpha$-lactalbumin made lethal to tumor cells). Int. J. Cancer 121:1352-1359.

Palmquist, D. L., and T. C. Jenkins. 2003. Challenges with fats and fatty acid methods. J. Anim. Sci. 81:3250-3254.

Pettersson, J., A.-K. Mossberg, and C. Svanborg. 2006. $\alpha$-Lactalbumin species variation, HAMLET formation, and tumor cell death. Biochem. Biophys. Res. Commun. 345:260-270.

Pettersson-Kastberg, J., S. Aits, L. Gustafsson, A. Mossberg, P. Storm, M. Trulsson, F. Persson, K. Hun Mok, and C. Svanborg. 2009. Can misfolded proteins be beneficial? The HAMLET case. Ann. Med. 41:162-176.

Rammer, P., L. Groth-Pedersen, T. Kirkegaard, M. Daugaard, A. Rytter, P. Szyniarowski, M. Høyer-Hansen, L. K. Povlsen, J. Nylandsted, J. E. Larsen, and M. Jäättelä. 2010. BAMLET activates a lysosomal cell death program in cancer cells. Mol. Cancer Ther. $9: 24-32$. 
Sternhagen, L. G., and J. C. Allen. 2001. Growth rates of a human colon adenocarcinoma cell line are regulated by the milk protein alpha-lactalbumin. Adv. Exp. Med. Biol. 501:115-120.

Svanborg, C., H. Ågerstam, A. Aronson, R. Bjerkvig, C. Düringer, W. Fischer, L. Gustafsson, O. Hallgren, I. Leijonhuvud, S. Linse, A. K. Mossberg, H. Nilsson, J. Pettersson, and M. Svensson. 2003. HAMLET kills tumor cells by an apoptosis-like mechanismCellular, molecular, and therapeutic aspects. Adv. Cancer Res. 88:1-29.

Svensson, M., J. Fast, A. K. Mossberg, C. Düringer, L. Gustafsson, O. Hallgren, C. L. Brooks, L. Berliner, S. Linse, and C. Svanborg. 2003a. $\alpha$-lactalbumin unfolding is not sufficient to cause apoptosis, but is required for the conversion to HAMLET (human $\alpha$-lactalbumin made lethal to tumor cells). Protein Sci. 12:27942804.

Svensson, M., A. Håkansson, A.-K. Mossberg, S. Linse, and C. Svanborg. 2000. Conversion of $\alpha$-lactalbumin to a protein inducing apoptosis. Proc. Natl. Acad. Sci. USA 97:4221-4226.

Svensson, M., A. K. Mossberg, J. Pettersson, S. Linse, and C. Svanborg. 2003b. Lipids as cofactors in protein folding: Stereo-specific lipid-protein interactions are required to form HAMLET (human $\alpha$-lactalbumin made lethal to tumor cells). Protein Sci. 12:28052814.

Thompson, M. P., H. M. Farrell, S. Mohanam, S. Liu, W. R. Kidwell, M. P. Bansal, R. G. Cook, D. Medina, C. E. Kotts, and M. Bano. 1992. Identification of human-milk $\alpha$-lactalbumin as a cell-growth inhibitor. Protoplasma 167:134-144.

Tolin, S., G. De Franceschi, B. Spolaore, E. Frare, M. Canton, P. Polverino de Laureto, and A. Fontana. 2010. The oleic acid complexes of proteolytic fragments of $\alpha$-lactalbumin display apoptotic activity. FEBS J. 277:163-173.

Xu, M., Y. Sugiura, S. Nagaoka, and Y. Kanamaru. 2005a. IEC-6 intestinal cell death induced by bovine milk alpha-lactalbumin. Biosci. Biotechnol. Biochem. 69:1082-1089.

Xu, M., Y. Sugiura, S. Nagaoka, and Y. Kanamaru. 2005b. Involvement of SDS-stable higher M(r) forms of bovine normal milk alpha-lactalbumin in inducing intestinal IEC-6 cell death. Biosci. Biotechnol. Biochem. 69:1189-1192.

Zhang, M., F. Yang Jr., F. Yang, J. Chen, C. Y. Zheng, and Y. Liang. 2009. Cytotoxic aggregates of alpha-lactalbumin induced by unsaturated fatty acid induce apoptosis in tumor cells. Chem. Biol. Interact. 180:131-142. 